\title{
Hypothalamic involvement predicts cardiovascular risk in adults with childhood onset craniopharyngioma on long-term GH therapy
}

\author{
Helene Holmer ${ }^{1,2}$, Bertil Ekman ${ }^{3}$, Jonas Björk ${ }^{4}$, Carl-Henrik Nordstöm ${ }^{5}$, Vera Popovic ${ }^{6}$, AnnBritt Siversson $^{2}$ \\ and Eva-Marie Erfurth ${ }^{2}$ \\ ${ }^{1}$ Department of Internal Medicine, Centralsjukhuset, Kristianstad, Lund, Sweden, ${ }^{2}$ Department of Endocrinology and Diabetes, Lund University Hospital, \\ SE-221 85 Lund, Sweden, ${ }^{3}$ Endocrine Unit, Division of Internal Medicine, Department of Medical and Health Sciences, University Hospital, Linköping, \\ Sweden, ${ }^{4}$ Competence Centre for Clinical Research, Lund University Hospital, Lund, Sweden, ${ }^{5}$ Department of Neurosurgery, University Hospital, Lund, \\ Sweden and ${ }^{6}$ Neuroendocrine Unit, Institute of Endocrinology, University Clinical Center, Belgrade, Serbia
}

(Correspondence should be addressed to E-M Erfurth; Email: eva_marie.erfurth@med.lu.se)

\begin{abstract}
Context: Craniopharyngioma patients without GH therapy are at an increased cardiovascular disease (CVD) risk and particularly concerning women. No previous study on long-term GH therapy in adults with childhood onset (CO) craniopharyngioma was identified.

Objective: To investigate CVD risk in adults with CO craniopharyngioma on complete hormone replacement, including long-term GH therapy, and to investigate the impact of disease-related factors on CVD risk.

Design and participants: In a cross-sectional study of operated CO craniopharyngiomas (1958-2000) from a defined area of Sweden ( 2.5 million), we enrolled 42 patients ( 20 women) with a median age of 28 years (range 17-57) and assessed CVD risk of 20 (4-40) years after first operation. Comparisons were made with matched controls and between patients with tumor growth into the third ventricle (TGTV) versus non-TGTV. GH therapy was 10-12 years in women and men.

Results: In comparison with controls, both male and female patients had increased body mass index, fat mass, insulin, and leptin levels. Overall, while not significantly increased in male patients, 55-60\% of female patients had a medium-high CVD risk, compared with 10-20\% in controls. An increased CVD risk (all $P<0.05$ ) and higher levels of fat mass and insulin were recorded in the TGTV group versus the non-TGTV group. Late puberty induction and lack of androgens were shown in female patients. Conclusions: Adult patients with CO craniopharyngioma, especially those with TGTV, have persistently increased CVD risk. Conventional hormone substitution, including GH, is insufficient to normalize CVD risk, suggesting an important role for irreversible hypothalamic dysfunction.
\end{abstract}

European Journal of Endocrinology 161 671-679

\section{Introduction}

In adult craniopharyngioma patients on conventional hormone therapy, but without GH therapy, an increased overall mortality $(1,2)$ and particularly cardiovascular mortality (1-3) have been shown, with a particularly high risk in women $(1,3)$. Craniopharyngioma is the most common tumor affecting the hypothalamicpituitary region in children and accounts for $6-9 \%$ of all pediatric brain tumors. Treatment may be achieved using either primary aggressive surgery, which may increase the risk of hypothalamic, neurological, endocrine, and visual damage (4), or conservative surgery followed by cranial radiotherapy (CRT), as an effective means of preventing recurrences (5). Approximately, $50 \%$ of children with a craniopharyngioma are obese at follow-up and hypothalamic damage seems to be a major cause $(4,6)$. Factors suggested to contribute include vagally mediated hyperinsulinemia and autonomic imbalance with consequences for energy balance and expenditure (7-9). Further, reduced sensitivity to endogenous leptin (10) and decreased physical activity (11), compounded by neurological defects and visual failure, have been documented $(1,3)$. Thus, there is evidence that hypothalamic damage per se is responsible for the manifestation of cardiovascular morbidity in patients with a craniopharyngioma, even though clinical evidence is presently lacking. Metabolic syndrome (MetS) has been shown in craniopharyngioma children, and hypothalamic damage together with $\mathrm{GH}$ deficiency (GHD) has been suggested to be responsible (12). In GH deficient children with craniopharyngioma, GH treatment improves linear growth but seems not to ameliorate their weight gain (13). The impact of long-term GH therapy in adults with childhood onset (CO) craniopharyngioma is, however, presently unknown. 
One aim of this cross-sectional study was to investigate the prevalence of cardiovascular risk factors in adults with childhood craniopharyngioma who were on complete hormone replacement therapy including longterm GH therapy. Another aim was to evaluate the impact of tumor growth on cardiovascular risk. Comparisons were made with population controls matched for age, gender, smoking habits, and residence as well as between patients with and without tumor growth into the third ventricle (TGTV) of the hypothalamus.

\section{Subjects and methods}

\section{Patients}

Study participants were 42 patients (20 women), aged $\geq 17$ years and recruited from 53 eligible subjects from the South Medical Region of Sweden (population 2.5 million). The patients were surgically treated for a childhood diagnosed craniopharyngioma, between years 1958 and 2000 and alive at the date of this study (20032004). Excluded subjects $(n=11)$ were assessed as unsuitable for participation by their respective physician (in dialysis, $n=1$; family reasons, $n=1$ ), too ill/tired $(n=4)$, or too busy $(n=4)$, or no reason given $(n=1)$.

Patient demographics, baseline characteristics, and tumor treatment modalities are shown in Table 1. Panhypopituitarism was present in 32 patients and out of which all but six patients had antidiuretic hormone deficiency. Twenty of the patients had received CRT with a median dose of $50 \mathrm{~Gy}$ (range 35-55 Gy) and three patients had received additional Yttrium installation. The median age at first operation was 12 years in women (3-20 years) and in men (3-22 years), and age at this study was 28 (18-57) years in women and 29 (17-57) years in men. The majority $(74 \%)$ of patients had one single operation. The most experienced neurosurgeon graded the tumor location based on the operation records (Table 1). Most patients (86\%) were receiving GH therapy at the time of the study. Two men had been on GH therapy for 6 years respectively but had previously stopped GH therapy for 1 and 8 years. Time since first operation to start of GH therapy was $3(0-35)$ years for women and $1(0-32)$ year for men, and treatment duration was 10 (3-19) years for women and 12 (3-33) years for men. Daily GH doses were $0.8(0.4-1.6) \mathrm{mg}$ in women and $0.5(0.2-1.0) \mathrm{mg}$ in men. Four patients (three women) were not GHD on GHRH-arginine testing.

Six patients (one woman) were treated for cardiovascular risk factors or disease and out of which all had TGTV together with panhypopituitarism and their body mass index (BMI) was $35(21-38) \mathrm{kg} / \mathrm{m}^{2}$. Their age at operation and time since operation was 13 (7-18) years and 36 (23-40) years respectively.

Seven women had menarche at 12 (10-14) years, but five of them had amenorrhea periods from 6 months to 3 years thereafter. The remaining 13 women had puberty induction at a median of 15 (12-18) years.
All these females were substituted with estrogens of 1-2 mg/day throughout the follow-up. At the time of study, $85 \%$ of them were on oral sex steroid replacement; 14 received combinations of oral gestagens and estrogens, of them 11 had 1-2 mg estradiol $\left(E_{2}\right) /$ day in combination with norethisterone of $1 \mathrm{mg} /$ day $(n=9)$ or medroxyprogesterone of $10 \mathrm{mg} /$ day $(n=2)$; and 3 had $<35 \mu$ g ethinyl $E_{2} /$ day in combination with levonorgestrel of maximum $150 \mu \mathrm{g} /$ day. Two women had estrogens only (1.25 mg conjugated estrogens/day) and one had only gestagens (150 mg medroxyprogesterone/ 3 months). One was postmenopausal and had $2 \mathrm{mg}$ of $\mathrm{E}_{2}$ with $1 \mathrm{mg}$ of norethisterone. Four women received DHEA or testosterone. The duration of DHEA therapy was 1 (1-3) year and the dose was 25 (25-50) mg. The remaining three women had regular menstrual cycles.

Most of the men (91\%) needed testosterone replacement, having started at 16 (10-24) years of age, and given injection every third to fourth week $(n=17)$, or as transdermal $(n=2)$ or oral $(n=1)$ therapy. Other hormone substitutions were thyroid hormones (21 men and 18 women), hydrocortisone ( 20 men and 16 women), and vasopressin (18 men and 17 women). Levothyroxine doses were 150 (30-200) $\mu \mathrm{g}$ in men and 150 (25-200) $\mu \mathrm{g}$ in women, and hydrocortisone doses were 22 (10-50) $\mathrm{mg}$ in men and $16(4-45) \mathrm{mg}$ in women. Five patients ( 2 women) had 35-50 mg hydrocortisone.

Visual acuity was normal $(\geq 0.8)$, and visual fields were normal or had minor defects in 19 (nine women) patients. Visual acuity was $\leq 0.5$ in one eye but normal in the other eye for nine (two women) patients and was $\leq 0.5$ in both eyes for six (two women) patients. Four (two women) patients were smokers.

\section{Control subjects and study design}

Each patient was matched with a control subject similar in age, sex, residence (rural/nonrural), and smoking habits, randomly selected from a computerized population register, as previously described (14). Out of 140 contacted controls, 19 declined to participate due to health reasons, 17 due to lack of time, 16 due to reluctance, and four due to pregnancy. Among female controls, seven used oral contraceptives with combinations of $35 \mu \mathrm{g}$ ethinyl $\mathrm{E}_{2}$ and $250 \mu \mathrm{g}$ levonorgestrel or up to $0.75 \mathrm{mg}$ norethisterone. One control was postmenopausal and without sex steroids.

The Ethics Committee of Lund University approved the protocol, and all subjects and patients gave written informed consent.

\section{Anthropometric measurements, blood pressure, criteria for MetS, and cardiovascular risk prediction}

Measurements of waist and hip circumference and ratio (WHR), body weight, body height, BMI, and blood pressure are described previously (14). Body composition was measured by bioelectric impedance analysis 
Table 1 Characteristics and treatment modalities in 42 patients with childhood onset craniopharyngioma.

\begin{tabular}{|c|c|c|c|c|c|c|}
\hline $\begin{array}{l}\text { Gender/age at } \\
\text { investigation } \\
\text { (year) }\end{array}$ & $\begin{array}{c}\text { Age at first } \\
\text { op (year) }\end{array}$ & $\begin{array}{l}\text { Tumor growth } \\
\text { (stage) }\end{array}$ & Treatments & Op no. & $\begin{array}{c}\text { BMI at } \\
\text { investigation } \\
\left(\mathrm{kg} / \mathrm{m}^{2}\right)\end{array}$ & $\begin{array}{c}\text { Hormone } \\
\text { substitutions }\end{array}$ \\
\hline$M / 57$ & 17 & 3 & $\mathrm{~S}+\mathrm{CRT}+\mathrm{Y}$ & 1 & 21 & $\mathrm{GH} / \mathrm{G} / \mathrm{T} / \mathrm{C}$ \\
\hline$M / 56$ & 18 & 3 & $\mathrm{~S}+\mathrm{CRT}$ & 1 & 32 & $\mathrm{GH} / \mathrm{G} / \mathrm{T} / \mathrm{C}$ \\
\hline $\mathrm{M} / 46$ & 18 & 3 & $\mathrm{~S}+\mathrm{CRT}$ & 1 & 26 & $\mathrm{GH} / \mathrm{G} / \mathrm{T} / \mathrm{C}$ \\
\hline $\mathrm{M} / 42$ & 9 & 3 & $\mathrm{~S}$ & 1 & 38 & $\mathrm{GH} / \mathrm{G} / \mathrm{T} / \mathrm{C} / \mathrm{ADH}$ \\
\hline $\mathrm{M} / 38$ & 12 & 3 & $\mathrm{~S}$ & 1 & 38 & $\mathrm{GH} / \mathrm{G} / \mathrm{T} / \mathrm{C} / \mathrm{ADH}$ \\
\hline$M / 36$ & 5 & 2 & $S$ & 2 & 27 & $\mathrm{GH} / \mathrm{G} / \mathrm{T} / \mathrm{C} / \mathrm{ADH}$ \\
\hline$M / 36$ & 15 & 2 & $\mathrm{~S}$ & 1 & 25 & $\mathrm{GH} / \mathrm{G} / \mathrm{T} / \mathrm{C} / \mathrm{ADH}$ \\
\hline$M / 35$ & 8 & 2 & $\mathrm{~S}$ & 1 & 25 & $\mathrm{GH} / \mathrm{G} / \mathrm{T} / \mathrm{C} / \mathrm{ADH}$ \\
\hline$M / 34$ & 11 & 3 & $\mathrm{~S}+\mathrm{CRT}$ & 1 & 38 & $\mathrm{GH} / \mathrm{G} / \mathrm{T} / \mathrm{C} / \mathrm{ADH}$ \\
\hline $\mathrm{M} / 33$ & 9 & 3 & $S+C R T$ & 2 & 37 & $\mathrm{G} / \mathrm{T} / \mathrm{C} / \mathrm{ADH}$ \\
\hline$M / 28$ & 17 & 2 & $\mathrm{~S}$ & 1 & 23 & $\mathrm{ADH}^{\mathrm{a}}$ \\
\hline $\mathrm{M} / 28$ & 16 & 3 & $\mathrm{~S}+\mathrm{CRT}$ & 1 & 26 & $\mathrm{GH} / \mathrm{G} / \mathrm{T} / \mathrm{C} / \mathrm{ADH}$ \\
\hline$M / 28$ & 3 & 2 & $\mathrm{~S}$ & 1 & 25 & $\mathrm{GH} / \mathrm{G} / \mathrm{T} / \mathrm{C} / \mathrm{ADH}$ \\
\hline$M / 28$ & 8 & 3 & $\mathrm{~S}+\mathrm{CRT}$ & 2 & 37 & $\mathrm{~T} / \mathrm{C} / \mathrm{ADH}$ \\
\hline$M / 26$ & 14 & 2 & $\mathrm{~S}$ & 1 & 23 & $\mathrm{GH} / \mathrm{G} / \mathrm{T} / \mathrm{C} / \mathrm{ADH}$ \\
\hline$M / 26$ & 14 & 2 & $\mathrm{~S}$ & 1 & 28 & $\mathrm{GH} / \mathrm{G} / \mathrm{T} / \mathrm{ADH}$ \\
\hline $\mathrm{M} / 25$ & 16 & 3 & $\mathrm{~S}+\mathrm{CRT}$ & 1 & 41 & $\mathrm{GH} / \mathrm{G} / \mathrm{T} / \mathrm{C} / \mathrm{ADH}$ \\
\hline$M / 25$ & 6 & 3 & $\mathrm{~S}+\mathrm{CRT}+\mathrm{Y}$ & 2 & 30 & $\mathrm{GH} / \mathrm{G} / \mathrm{T} / \mathrm{C} / \mathrm{ADH}$ \\
\hline$M / 23$ & 22 & 3 & $\mathrm{~S}+\mathrm{CRT}$ & 1 & 29 & $\mathrm{GH} / \mathrm{G} / \mathrm{T} / \mathrm{C} /$ \\
\hline $\mathrm{M} / 19$ & 6 & 3 & $\mathrm{~S}+\mathrm{CRT}$ & 3 & 28 & $\mathrm{GH} / \mathrm{G} / \mathrm{T} / \mathrm{C} / \mathrm{ADH}$ \\
\hline $\mathrm{M} / 17$ & 7 & 3 & $\mathrm{~S}+\mathrm{CRT}$ & 1 & 31 & $\mathrm{GH} / \mathrm{G} / \mathrm{T} / \mathrm{C} / \mathrm{ADH}$ \\
\hline$M / 17$ & 4 & 2 & $\mathrm{~S}+\mathrm{CRT}$ & 1 & 25 & $\mathrm{GH} / \mathrm{G} / \mathrm{T} / \mathrm{C} / \mathrm{ADH}$ \\
\hline$F / 57$ & 18 & 3 & $\mathrm{~S}+\mathrm{CRT}$ & 3 & 24 & $\mathrm{GH} / \mathrm{G} / \mathrm{T} / \mathrm{C} / \mathrm{ADH}$ \\
\hline $\mathrm{F} / 46$ & 7 & 3 & $S$ & 3 & 38 & $\mathrm{GH} / \mathrm{G} / \mathrm{T} / \mathrm{C} / \mathrm{ADH}$ \\
\hline $\mathrm{F} / 46$ & 7 & 3 & $\mathrm{~S}+\mathrm{CRT}$ & 2 & 41 & $\mathrm{GH} / \mathrm{G} / \mathrm{T} / \mathrm{C}$ \\
\hline $\mathrm{F} / 41$ & 12 & 2 & $\mathrm{~S}$ & 1 & 23 & $\mathrm{C} / \mathrm{ADH}^{\mathrm{a}}$ \\
\hline $\mathrm{F} / 40$ & 3 & 3 & $\mathrm{~s}$ & 1 & 32 & $\mathrm{GH} / \mathrm{G} / \mathrm{T} / \mathrm{C} / \mathrm{ADH}$ \\
\hline$F / 37$ & 12 & 2 & $\mathrm{~S}$ & 1 & 34 & $\mathrm{~T} / \mathrm{ADH}^{\mathrm{a}}$ \\
\hline$F / 32$ & 12 & 3 & $\mathrm{~S}$ & 1 & 35 & $\mathrm{GH} / \mathrm{G} / \mathrm{T} / \mathrm{ADH}$ \\
\hline$F / 31$ & 11 & 1 & $S$ & 1 & 31 & $\mathrm{GH} / \mathrm{T} / \mathrm{C} / \mathrm{ADH}$ \\
\hline$F / 28$ & 20 & 2 & $\mathrm{~S}+\mathrm{CRT}$ & 1 & 26 & $\mathrm{GH} / \mathrm{G} / \mathrm{T} / \mathrm{C}$ \\
\hline$F / 28$ & 9 & 2 & $\mathrm{~s}$ & 1 & 35 & $\mathrm{GH} / \mathrm{G} / \mathrm{T} / \mathrm{C} / \mathrm{ADH}$ \\
\hline$F / 29$ & 20 & 3 & $\mathrm{~S}$ & 1 & 33 & $\mathrm{G} / \mathrm{T}^{\mathrm{a}}$ \\
\hline $\mathrm{F} / 27$ & 14 & 1 & $\mathrm{~S}$ & 1 & 25 & $\mathrm{GH} / \mathrm{G} / \mathrm{T} / \mathrm{C} / \mathrm{ADH}$ \\
\hline$F / 24$ & 15 & 2 & $\mathrm{~S}$ & 1 & 20 & $\mathrm{GH} / \mathrm{G} / \mathrm{ADH}$ \\
\hline $\mathrm{F} / 23$ & 3 & 3 & $\mathrm{~S}+\mathrm{CRT}+\mathrm{Y}$ & 2 & 28 & $\mathrm{GH} / \mathrm{G} / \mathrm{T} / \mathrm{C} / \mathrm{ADH}$ \\
\hline$F / 23$ & 6 & 3 & $\mathrm{~S}+\mathrm{CRT}$ & 2 & 30 & $\mathrm{GH} / \mathrm{G} / \mathrm{T} / \mathrm{C} / \mathrm{ADH}$ \\
\hline$F / 22$ & 15 & 3 & $S+C R T$ & 1 & 28 & $\mathrm{GH} / \mathrm{G} / \mathrm{T} / \mathrm{C} / \mathrm{ADH}$ \\
\hline $\mathrm{F} / 22$ & 10 & 2 & $S$ & 1 & 30 & $\mathrm{GH} / \mathrm{G} / \mathrm{T} / \mathrm{C} / \mathrm{ADH}$ \\
\hline $\mathrm{F} / 20$ & 17 & 1 & $\mathrm{~s}$ & 1 & 19 & $\mathrm{GH} / \mathrm{G} / \mathrm{T} / \mathrm{C} / \mathrm{ADH}$ \\
\hline$F / 18$ & 13 & 3 & $\mathrm{~S}$ & 1 & 31 & $\mathrm{GH} / \mathrm{G} / \mathrm{T} / \mathrm{C} / \mathrm{ADH}$ \\
\hline$F / 17$ & 4 & 3 & $\mathrm{~S}+\mathrm{CRT}$ & 3 & 34 & $\mathrm{GH} / \mathrm{G} / \mathrm{T} / \mathrm{C} / \mathrm{ADH}$ \\
\hline
\end{tabular}

M, male; F, female; 1, intrasellar growth; 2, suprasellar growth; 3, suprasellar growth towards the third ventricle; S, surgery, CRT, cranial radiotherapy; $\mathrm{Y}$, Yttrium installation; G, gonadal steroids; T, levothyroxine; C, cortisone; $\mathrm{ADH}$, antidiuretic hormone.

${ }^{\mathrm{a}} \mathrm{Not} \mathrm{GH}$ deficient at testing.

(BIA) 101-S technique (RJL Systems, Detroit, MI, USA) with a $50-\mathrm{KHz}, 800-\mu \mathrm{A}$ instrument; $\mathrm{kg}$ of fat and fatfree mass were determined from equations supplied by the manufacturer, and percentages were calculated from body weight. Muscle mass was calculated from the equation by Janssen et al. (15).

MetS was defined according to the International Diabetes Federation (IDF) guidelines (16) with central obesity (waist $\geq 94 \mathrm{~cm}$ in men and $\geq 80 \mathrm{~cm}$ in women) as a key issue in association with two or more of the following: i) elevated triglycerides (TGs), ii) elevated fasting plasma glucose, iii) raised blood pressure, iv) reduced high-density lipoprotein cholesterol (HDL-C).

Risk of cardiovascular disease (CVD) was assessed by serum levels of high-sensitivity C-reactive protein
(hs-CRP) and low-density lipoprotein cholesterol (LDL-C). hs-CRP $>1 \mathrm{mg} / \mathrm{l}$ and/or LDL-C $>3.4 \mathrm{mmol} / \mathrm{l}$ indicate 1.7 times increased risk or more of CVD events $(17,18)$. The ratio of the lipid-transporting apolipoproteins (ApoB/ApoA-I) was used to calculate the risk of myocardial infarction (19). In women $>0.6$ and in men $>0.7$ was regarded as medium-high risk, and ratio $>0.8$ in women and $>0.9$ in men was regarded as high risk.

\section{Assessments of physical activity}

To assess physical exercise during leisure time and work time, a self-rating questionnaire, classified into a fourgrade scale, was used (20). Patients and controls were 
interviewed by a dietician and asked to describe their daily activity pattern that was assessed in periods of 15-min intervals as either 'active' (standing, walking, housework, sports) or 'inactive' (sleeping, lying down, reading, sitting, watching television). Average physical activity was determined from pedometer readings over a 3-day period (21). Participants wore their pedometer on the same weekdays.

\section{Biochemical assays}

Blood samples were drawn in the morning fasting and before drug intake. Details of assay procedures for plasma glucose, serum levels of insulin-like growth factor 1 (IGF1), and plasma levels of TSH, free thyroxine $\left(\mathrm{T}_{4}\right)$, free tri-iodothyronine $\left(\mathrm{T}_{3}\right)$, cortisol, FSH, and $\mathrm{LH}$ are presented elsewhere (14). Serum leptin was measured by RIA (Linco, St Charles, MO, USA) with a detection limit of $0.5 \mathrm{ng} / \mathrm{ml}$ and within assay coefficient of variation $(\mathrm{CV})$ of $<6 \%$. Serum DHEA levels were measured by competitive immunoassay with inter- and intraassay $\mathrm{CV}<12.6 \%$. Standard procedures for plasma LDL-C, HDL-C, ApoA-I, ApoB, TG, fibrinogen, $\mathrm{E}_{2}$ and serum hs-CRP, sex hormone-binding globulin (SHBG) and testosterone were used.

\section{Statistical analysis}

Data are presented as median (range $=\min -\max$ ). The Wilcoxon signed-rank test for matched pairs was used to compare patient and control data. Bivariate correlations were analyzed using the Spearman rank correlation coefficient. Binary outturns between patients and controls were compared using McNemar's test. The Mann-Whitney U-test with two independent groups was used to evaluate differences in anthropometric and BIA measurements, cardiovascular risk factors and plasma and serum hormonal levels due to tumor growth. In multiple linear regressions with leptin, insulin, LDL-C, HDL-C, and ApoB/ApoA-I ratio as dependent variables, patient/control status ( $1=$ patient, $0=$ control) and BMI were used as independent variables. Multiple linear regressions were also performed for muscle mass $(\mathrm{kg})$ with patient/control status and total body weight as independent variables. All regression analyses were conducted separately for males and females. We regarded $P<0.05$ as statistically significant.

\section{Results}

\section{Prevalence of CVD and MetS}

Six patients (one woman) were on treatment for cardiovascular risk factors or CVD: one man had diabetes mellitus treated with insulin, four patients (one woman) had antihypertensive treatment, and three men had lipid-lowering drugs. Corresponding morbidity among controls was one man on lipid lowering and one man on antihypertensive drugs. Eight patients (three women) and three controls (all men) fulfilled the criteria for MetS according to IDF. There were significantly more patients on treatment for CVD and/or with the MetS compared with controls (11 vs $3, P=0.04$ ).

\section{Cardiovascular risk factors, risk predictions for CVD, and anthropometric measurements in patients compared with controls}

Serum insulin levels, but not plasma glucose levels, were significantly higher in patients than in controls (Table 2). Plasma levels of LDL-C, TG, fibrinogen, hs-CRP, and ApoB/ApoA-I ratio were significantly higher in female, but not in male patients, versus controls.

Risk for CVD, assessed by hs-CRP and LDL-C levels, was increased (intermediate levels) in $20(48 \%)$ patients (11 women, 55\%) and in 12 (29\%) controls (2 women, $10 \%)$. Using the ApoB/ApoA-I ratio, elevated CVD risk (medium or high) was identified in $22(52 \%)$ patients (12 women, 60\%) and 14 (33\%) controls (4 women, $20 \%$ ). Levels of serum leptin and leptin $/ \mathrm{kg}$ fat mass were significantly higher in male and female patients than in controls.

After linear regression, and with adjustment for BMI, no significant differences were recorded for insulin, LDL-C, and ApoB/ApoA-I ratio in females $(P \geq 0.08$, all $)$, or for insulin in male patients, as compared with controls $(P>0.3)$. Serum leptin levels were significantly higher in both male and female patients, even when BMI was included in the model (males $P=0.03$ and females $P=0.002$ ).

Weight and BMI were significantly higher in patients compared with controls. Both in percentage and kg, male as well as female patients had significantly increased fat mass. No difference was recorded in $\mathrm{kg}$ muscle mass, but significantly lower percentage of muscle mass was recorded in patients of both genders. However, this difference remained only in the male patients $(P=0.049)$ when the increased weight of the patients was taken into account in a multiple regression analysis.

Blood pressure and heart rate did not differ in either gender, in comparison with controls.

\section{Hormone assessments and evaluation of physical exercise between patients and controls}

At evaluation, the serum IGF1 levels were without difference between patients and controls of both genders (Table 2). Levels of plasma free $\mathrm{T}_{4}$ were significantly higher in patients compared with controls, while plasma free $\mathrm{T}_{3}$ levels were only significantly lower in male patients compared with controls, but within normal ranges for both hormones 
Table 2 Cardiovascular risk factors, hormone assessments, and anthropometric measurements in 42 childhood onset craniopharyngioma patients and in 42 matched controls.

\begin{tabular}{|c|c|c|c|c|c|c|}
\hline & \multicolumn{2}{|c|}{ Women median (range) } & \multicolumn{2}{|c|}{ Men median (range) } & \multicolumn{2}{|c|}{$P$ value } \\
\hline & Patients $(n=20)$ & Controls $(n=20)$ & Patients $(n=22)$ & Controls $(n=22)$ & Women & Men \\
\hline \multicolumn{7}{|c|}{ Biochemical measures } \\
\hline S-insulin (mIU/l) & $6.0(2.0-16.0)$ & $3.0(2.0-16.0)$ & $5.5(1.0-38.0)$ & $4.0(1.0-7.0)$ & 0.004 & 0.02 \\
\hline Insulin/kg fat mass & $0.17(0.09-0.37)$ & $0.21(0.05-0.28)$ & $0.20(0.05-0.59)$ & $0.20(0.07-0.33)$ & $>0.3$ & $>0.3$ \\
\hline P-glucose $(\mathrm{mmol} / \mathrm{l})$ & $4.4(3.6-5.8)$ & $4.9(3.7-5.4)$ & $4.5(3.7-11.1)$ & $4.6(3.7-5.9)$ & 0.08 & $>0.3$ \\
\hline P-HDL $(\mathrm{mmol} / \mathrm{l})$ & $1.49(0.9-2.4)$ & $1.8(1.3-2.2)$ & $1.2(0.8-2.4)$ & $1.3(0.8-2.2)$ & 0.09 & 0.19 \\
\hline P-LDL (mmol/l) & $3.4(2.2-4.6)$ & $2.7(1.2-4.0)$ & $2.9(0.5-5.3)$ & $3.2(1.6-5.4)$ & 0.01 & $>0.3$ \\
\hline ApoB/ApoA-I ratio & $0.67(0.35-1.08)$ & $0.46(0.23-0.71)$ & $0.68(0.37-1.40)$ & $0.64(0.29-2.00)$ & 0.01 & $>0.3$ \\
\hline P-TG $(\mathrm{mmol} / \mathrm{l})$ & $1.2(0.4-2.4)$ & $0.8(0.3-1.8)$ & $1.2(0.6-8.5)$ & $1.2(0.3-3.7)$ & 0.03 & $>0.3$ \\
\hline P-fibrinogen (g/l) & $3.7(2.4-4.0)$ & $3.1(2.3-4.1)$ & $2.7(2.0-4.6)$ & $3.0(2.0-3.9)$ & 0.004 & $>0.3$ \\
\hline P-hs-CRP (mg/l) & $3.6(0.4-23.0)$ & $0.4(0.4-13.0)$ & $0.7(0.4-17)$ & $0.4(0.4-9.6)$ & 0.02 & $>0.3$ \\
\hline S-leptin (ng/ml) & $33.8(16.0-214)$ & $10.6(3.3-36.9)$ & $15.3(2.7-57.0)$ & $4.7(1.7-22.3)$ & $<0.001$ & 0.007 \\
\hline Leptin/kg fat mass & $1.13(0.73-4.51)$ & $0.68(0.29-1.40)$ & $0.45(0.16-1.02)$ & $0.22(0.12-0.83)$ & 0.001 & 0.04 \\
\hline S-IGF1 ( $\mu \mathrm{g} / \mathrm{I})$ & $205(70-328)$ & $201(125-385)$ & $182(35-536)$ & $203(125-315)$ & $>0.3$ & $>0.3$ \\
\hline P-free $T_{4}(\mathrm{pmol} / \mathrm{l})$ & $19(13-26)$ & $15(13-21)$ & $18(15-31)$ & $17(14-21)$ & 0.02 & 0.01 \\
\hline P-free $T_{3}(\mathrm{pmol} / \mathrm{l})$ & $5.1(2.8-6.9)$ & $5.4(4.2-7.8)$ & $4.6(2.9-5.2)$ & $6.0(4.6-6.9)$ & 0.11 & $<0.001$ \\
\hline \multicolumn{7}{|c|}{ Anthropometric measurements } \\
\hline Height $(\mathrm{cm})$ & $172(155-177)$ & $168(160-175)$ & $180(163-193)$ & $180(170-193)$ & $>0.3$ & $>0.3$ \\
\hline Weight $(\mathrm{kg})$ & $93(53-122)$ & $60(49-108)$ & $92(60-149)$ & $82(58-111)$ & $<0.001$ & 0.03 \\
\hline $\operatorname{BMI}\left(\mathrm{kg} / \mathrm{m}^{2}\right)$ & $31(19-41)$ & $21(18-36)$ & $28(21-41)$ & $24(20-34)$ & $<0.001$ & 0.02 \\
\hline Waist $(\mathrm{cm})$ & $95(72-126)$ & $72(64-114)$ & $100(77-131)$ & $90(73-108)$ & $<0.001$ & 0.006 \\
\hline Waist:hip ratio & $0.9(0.8-1.0)$ & $0.8(0.7-1.0)$ & $0.9(0.8-1.0)$ & $1.0(0.8-1.1)$ & 0.003 & 0.15 \\
\hline \multicolumn{7}{|c|}{ Body composition (BIA) } \\
\hline Fat mass $(\mathrm{kg})$ & $39(13-62)$ & $16(8-47)$ & $27(9-64)$ & $18(9-38)$ & $<0.001$ & 0.006 \\
\hline Fat mass $(\%)$ & $42(24-52)$ & $26(15-43)$ & $31(16-46)$ & $21(14-34)$ & $<0.001$ & 0.003 \\
\hline Muscle mass $(\mathrm{kg})$ & $22(18-27)$ & $20(17-28)$ & $33(23-40)$ & $32(27-37)$ & 0.2 & $>0.3$ \\
\hline Muscle mass (\%) & $27(20-37)$ & $34(26-43)$ & $35(24-43)$ & $40(31-47)$ & $<0.001$ & 0.003 \\
\hline Fat free mass $(\mathrm{kg})$ & $49(40-60)$ & $45(37-61)$ & $66(47-86)$ & $64(48-73)$ & 0.002 & 0.3 \\
\hline Fat free mass $(\%)$ & $58(48-76)$ & $74(57-85)$ & $69(54-84)$ & $79(66-86)$ & $<0.001$ & 0.003 \\
\hline
\end{tabular}

$\mathrm{S}$, serum; $\mathrm{P}$, plasma; ApoA-I, apolipoprotein $\mathrm{A}-\mathrm{I} ; \mathrm{ApoB}$, apolipoprotein $\mathrm{B}$; body composition parameters measured with bioelectrical impedance analysis (BIA); $\mathrm{HDL}$, high-density lipoprotein; hs-CRP, high sensitivity C-reactive protein; LDL, low-density lipoprotein; TG, triglyceride; IGF1, insulin-like growth factor 1.

(Table 2). In female patients, serum DHEA (1.8 vs $3.7 \mu \mathrm{mol} / \mathrm{l}, P<0.006)$ and testosterone levels (0.4 vs $1.2 \mathrm{nmol} / \mathrm{l}, \mathrm{P}<0.003)$ were significantly lower than in controls, but with no difference for serum testosterone levels in males.

In comparison with controls, male patients had significantly lower levels of leisure-time physical activity (winter and summer), while for female patients only winter leisure-time physical activity levels were significantly reduced (Table 3). Work-time physical activity was comparable between patients and controls. Estimated active time and activity as assessed by pedometer were significantly lower in male patients only.

\section{Tumor characteristics, cardiovascular risk factors, and hormone assessments in patients with and without TGTV}

Data from 25 (11 women) patients with TGTV were compared with 17 (nine women) patients without TGTV (non-TGTV; Table 4). TGTV patients had significantly more operations $(\geq 2$ operations; ten versus one patient, $P=0.01$ ) and were more often treated with CRT (18 vs 2 patients, $P<0.001)$ than patients without TGTV. Otherwise, there were no significant differences between patients with and without TGTV in physical activity (any modality), gender, age or time since first operation, dose of radiotherapy, number of pituitary deficiencies, age at or time since start of GH therapy, or number of patients with severe visual disturbances (data not shown). The number of patients with ACTH or TSH deficiency and doses of hydrocortisone or levothyroxine, was not different between patient groups. Serum-free $\mathrm{T}_{4}$ levels were significantly higher, but no differences were recorded in serum-free $\mathrm{T}_{3}$ or IGF1 levels. Blood pressure was without differences between groups.

Patients with TGTV had significantly higher weight, BMI, waist, fat mass, and lower fat-free mass compared with patients without TGTV (Table 4). Serum insulin levels and insulin per $\mathrm{kg}$ fat mass were also significantly increased in patients with TGTV. Ten out of 11 patients receiving treatment for CVD and/or with MetS belonged to the TGTV group (Table 4). CVD risk in patients with TGTV, assessed by hs-CRP and LDL-C levels, was increased (intermediate levels) in $64 \%$ in the TGTV group, compared with $24 \%$ in the non-TGTV group (Table 4), and nine out of 11 females in the TGTV group had such risk compared with two out of nine females in the non-TGTV group. Significantly higher insulin levels were recorded in females with TGTV versus females without TGTV $(P<0.007)$. 
Table 3 Physical activity evaluated by the participants at a four-grade scale at work and in leisure time during summer and winter, and as estimated active and inactive time during an ordinary day and by counting steps for 3 days with a pedometer.

\begin{tabular}{|c|c|c|c|c|c|c|c|}
\hline & & \multicolumn{2}{|c|}{ Women } & \multicolumn{2}{|c|}{ Men } & \multicolumn{2}{|c|}{$P$ value } \\
\hline & & Patients $n(\%)$ & Controls $n(\%)$ & Patients $n(\%)$ & Controls $n(\%)$ & Women & Men \\
\hline \multirow{4}{*}{$\begin{array}{l}\text { Physical activity at } \\
\text { work }^{\mathrm{a}}\end{array}$} & 1 & $5(42)$ & $5(42)$ & $10(67)$ & $6(40)$ & \multirow[t]{4}{*}{$>0.3$} & \multirow[t]{4}{*}{0.11} \\
\hline & 2 & $4(33)$ & $7(58)$ & $2(13)$ & $3(20)$ & & \\
\hline & 3 & $3(25)$ & $0(0)$ & $3(20)$ & $4(27)$ & & \\
\hline & 4 & $0(0)$ & $0(0)$ & $0(0)$ & $2(13)$ & & \\
\hline Physical activity & 1 & $0(0)$ & $0(0)$ & $4(18)$ & $1(5)$ & \multirow[t]{4}{*}{0.19} & \multirow[t]{4}{*}{0.04} \\
\hline \multirow[t]{3}{*}{ leisure time summer } & 2 & $12(60)$ & $9(45)$ & $11(50)$ & $9(41)$ & & \\
\hline & 3 & $8(40)$ & $9(45)$ & $7(32)$ & $9(41)$ & & \\
\hline & 4 & $0(0)$ & $2(9)$ & $0(0)$ & $3(14)$ & & \\
\hline Physical activity & 1 & $3(15)$ & $2(10)$ & 7 (32) & $1(5)$ & \multirow[t]{5}{*}{0.046} & \multirow[t]{5}{*}{0.01} \\
\hline \multirow{4}{*}{ leisure time winter } & 2 & $10(50)$ & $6(30)$ & $9(41)$ & $10(45)$ & & \\
\hline & 3 & 7 (35) & 7 (35) & $6(27)$ & $9(41)$ & & \\
\hline & 4 & $0(0)$ & $5(25)$ & $0(0)$ & $2(9)$ & & \\
\hline & & Median (range) & Median (range) & Median (range) & Median (range) & & \\
\hline \multirow{3}{*}{\multicolumn{2}{|c|}{ 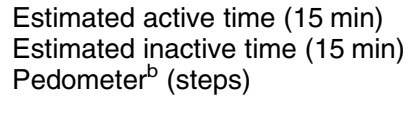 }} & $20(9-63)$ & $28(14-49)$ & $16(3-45)$ & $26(9-54)$ & 0.21 & 0.02 \\
\hline & & $76(33-87)$ & $68(47-82)$ & $80(51-93)$ & $70(42-87)$ & 0.21 & 0.02 \\
\hline & & $\begin{array}{l}23870 \\
\quad(6081-48800)\end{array}$ & $\begin{array}{l}32422 \\
\quad(18684-31154)\end{array}$ & $\begin{array}{l}21395 \\
\quad(9758-51993)\end{array}$ & $\begin{array}{l}30382 \\
\quad(2062-64043)\end{array}$ & 0.12 & 0.02 \\
\hline
\end{tabular}

1, sedentary life or work; 2, light activity in spare time or soft work; 3, regular physical activity or moderate hard work; 4, hard exercise or hard work.

aSeven pairs of men and eight pairs of women were excluded from the analysis as they were not 'working'.

${ }^{\mathrm{b}}$ Three pairs of women did not participate due to technical problems with the pedometer.

\section{Correlations between disease-related factors to cardiovascular risk factors and CVD risk predictions}

Tumor extension correlated in both men and women with plasma insulin $(r=0.57, P<0.001$, Fig. 1$)$, and in all patients to waist $(r=0.49, P=0.001)$, fat mass $(r=0.46, P<0.04)$, WHR $(r=0.39, P=0.01)$, and blood pressure $\geq 135 / 85$ ( $r=0.45, P=0.003)$. Years since first operation and age at first operation correlated to waist $(r=0.33, P=0.034$ and $r=-0.32, P=0.04$ respectively). Among female patients, no significant correlations were recorded between age at puberty induction/menarche to BMI, or to CVD risk predictions (all $P>0.2)$. No significant correlation $(P>0.2)$ was recorded between fat mass and the dose of hydrocortisone.

\section{Discussion}

This study is the first to show the prevalence of cardiovascular risk in adults with CO craniopharyngioma on complete hormone replacement, including 10-12 years of GH therapy throughout childhood and adolescence. Compared with population controls, significant increases in BMI, fat mass, insulin, and leptin levels were recorded in both male and female craniopharyngioma patients, but with a higher cardiovascular risk among the females. Of female craniopharyngioma patients $55-60 \%$ compared with $10-20 \%$ of the controls fulfilled the criteria for 'medium-high CVD risk', predictors for diabetes mellitus and cardiovascular events (22). In contrast, 'CVD risk indicators' were not different between male craniopharyngioma patients and controls. However, hypothalamic damage from the tumor was clearly more important than female gender risk, as shown by the higher 'CVD risk' and insulin levels among the females in the TGTV group compared with females in the non-TGTV group. Furthermore, the tumor extension correlated positively with the insulin levels in both genders.

Hypothalamic damage may result in vagally mediated hyperinsulinemia, which is a contributing mechanism for excess fat mass accumulation and high BMI, resulting in obesity and deranged lipid levels $(7,23)$. Higher insulin levels and insulin/ $\mathrm{kg}$ fat mass shown in the TGTV group may also be due to lack of sensitivity to insulin. Whether patients in the present study were insulin resistant requires further investigations using clamp techniques. The high BMI shown in both genders was, however, the most important link to CVD risk, as after adjustment for BMI all differences in cardiovascular risk factors, except for leptin disappeared. Thus, leptin was unaffected by the adjustment for BMI indicating lack of sensitivity to endogenous leptin, and this may further lead to disruption of the control of hunger and satiety and to reduced energy expenditure (24). In the TGTV group, other possible contributing mechanisms include: altered regulation of central sleep-wake cycle with increased daytime sleepiness (25), autonomic imbalance $(9,26)$, as well as reduced physical activity. Long-term GH therapy, as shown in the present study, was unable to affect the increased fat mass, while the muscle mass in absolute terms was normal suggesting that GH had the expected anabolic effect in these patients. Plasma glucose levels remained normal, reflecting sufficient skeletal muscle 
Table 4 Anthropometric measurements, cardiovascular disease risk (CVD), and risk factors in patients with tumor growth into the third ventricle (TGTV) and without (non-TGTV).

\begin{tabular}{|c|c|c|c|}
\hline & $\begin{array}{l}\text { TGTV }(n=25, \\
\text { (women=11) } \\
\text { Median (range) }\end{array}$ & $\begin{array}{l}\text { Non-TGTV }(n=17, \\
\text { (women =9) } \\
\text { Median (range) }\end{array}$ & $\boldsymbol{P}$ \\
\hline \multicolumn{4}{|c|}{ Anthropometric measurements and body composition (BIA) } \\
\hline Weight $(\mathrm{kg})$ & $96(60-149)$ & $80(53-110)$ & 0.001 \\
\hline BMI $\left(\mathrm{kg} / \mathrm{m}^{2}\right)$ & $32(21-41)$ & $25(19-35)$ & 0.001 \\
\hline Waist (cm) & $105(77-131)$ & $89(72-109)$ & 0.002 \\
\hline WHR & $0.94(0.83-1.05)$ & $0.88(0.76-0.99)$ & 0.02 \\
\hline Fat mass $(\mathrm{kg})$ & $40(9-64)$ & $20(13-56)$ & 0.003 \\
\hline Fat mass (\%) & $39(16-51)$ & $30(19-52)$ & 0.04 \\
\hline Muscle mass (kg) & $44(19-59)$ & $25(21-60)$ & 0.4 \\
\hline Muscle mass (\%) & $35(12-44)$ & $28(15-44)$ & 0.8 \\
\hline Fat free mass (kg) & $57(41-86)$ & $51(40-68)$ & 0.015 \\
\hline Fat free mass (\%) & $61(49-84)$ & $70(48-81)$ & 0.04 \\
\hline \multicolumn{4}{|l|}{ CVD risk and risk factors } \\
\hline Increased CVD risk (HDL-C + hs-CRP) & $16 / 25(64 \%)$ & $4 / 17(24 \%)$ & $<0.006$ \\
\hline CVD treatment/MetS (IDF) & 10 & 1 & $<0.02$ \\
\hline P-leptin (ng/ml) & $28(4-215)$ & $16(3-67)$ & 0.07 \\
\hline Leptin/kg fat mass (BIA) & $0.74(0.26-4.51)$ & $0.95(0.16-1.56)$ & $>0.3$ \\
\hline S-insulin (mIU/l) & $7(2-38)$ & $4(1-8)$ & $<0.001$ \\
\hline Insulin/kg fat mass (BIA) & $0.21(0.05-0.59)$ & $0.15(0.06-0.35)$ & 0.047 \\
\hline P-glucose $(\mathrm{mmol} / \mathrm{l})$ & $4.6(3.6-11.0)$ & $4.4(3.7-5.9)$ & $>0.3$ \\
\hline P-LDL $(\mathrm{mmol} / \mathrm{l})$ & $2.9(0.5-5.4)$ & $3.2(2.2-4.7)$ & 0.23 \\
\hline $\mathrm{P}-\mathrm{HDL}(\mathrm{mmol} / \mathrm{l})$ & $1.2(0.7-8.5)$ & $1.3(0.9-2.4)$ & 0.23 \\
\hline ApoB/ApoA-I ratio & $0.68(0.35-1.40)$ & $0.66(0.37-1.09)$ & $>0.3$ \\
\hline P-fibrinogen $(g / l)$ & $3(2-5)$ & $3(2-4)$ & $>0.3$ \\
\hline P-hs-CRP (mg/l) & $2.8(0.4-23)$ & $0.4(0.4-16)$ & 0.07 \\
\hline
\end{tabular}

P, plasma; S, serum; ApoA-I, apolipoprotein A-I; ApoB, apolipoprotein B; BIA, bioelectric impedance analysis; HDL-C, high-density lipoprotein cholesterol; hs-CRP, high sensitivity C-reactive protein; IGF1, insulin-like growth factor 1; LDL-C, low-density lipoprotein cholesterol; MetS, metabolic syndrome; WHR, waist/hip circumference ratio.

mass, which is of principal importance in the maintenance of glucose homeostasis (27).

Based on the very low annual incidence of $\mathrm{CO}$ craniopharyngioma of 0.4 /million person years (28) and a background population of 2.5 million, the number of included patients may seem limited, but is nevertheless representative for all deceased craniopharyngioma

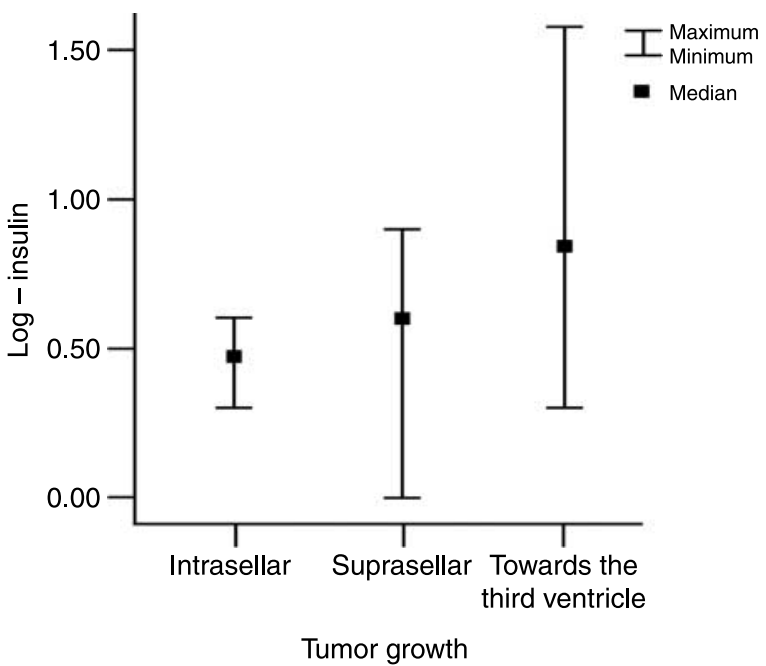

Figure 1 Correlation between tumor growth and the logarithm for serum insulin for all patients, $r=0.57, P<0.001$; for men, $r=0.53$, $P=0.011$; and for women, $r=0.66, P=0.002$. patients during 42 years in this area of Sweden and is thus representative for the entire surviving adult population of $\mathrm{CO}$ craniopharyngioma. However, as this cohort is a cross-section of survivors, we cannot exclude that nonsurvivors may have exhibited a different demographic profile from our study cohort.

One goal when treating craniopharyngioma patients is to reach a cardiovascular risk comparable with that of the general population, but currently reference values for cardiovascular risk factors or body composition parameters are not available in Sweden in such a young cohort. Thus, we matched for variables as smoking, gender, age, and residence, but not for BMI or fat mass, as these variables were considered as outcome measures. Even if this control group represents a selected population we consider it appropriate as a similar percentage of patients $(9 \%)$ and controls $(14 \%)$ declined to participate due to health reasons. However, based on data from Statistics Sweden (www.scb.se), the median BMI for Swedish subjects age matched to our patient population is $23 \mathrm{~kg} / \mathrm{m}^{2}$ for women and $25 \mathrm{~kg} / \mathrm{m}^{2}$ for men in comparison with 21 and $24 \mathrm{~kg} / \mathrm{m}^{2}$ respectively in our control subjects. Thus, the relative difference in BMI between patients and controls is reduced from 48 to $35 \%$ for women and from 17 to $12 \%$ for men, but was not considered to alter the findings of this study.

The majority of craniopharyngioma patients were on long-term GH therapy, and effectiveness of GH dosing is 
shown by similarities in the achieved height and IGF 1 levels in patients in comparison with controls. However, we cannot exclude that over- or under replacement with GH may have occurred previously. Thus, the exact benefit of GH therapy cannot be elucidated based on the present study design, as no control group of CO craniopharyngioma patients without $\mathrm{GH}$ therapy is available in Sweden. Further, recent consensus statements (29) suggest that GH therapy should be recommended in patients with reconfirmed GHD to at least their mid-20s as there are negative consequences on somatic maturation if GH replacement is interrupted (30). Positive effects of continued treatment on fat distribution, muscle mass, cardiac function, and bone mass have been shown $(31,32)$. However, in the present study, GH therapy was insufficient to influence the much increased fat mass, which agrees with previous results of 2 years of GH therapy in adult onset craniopharyngiomas (33).

In GHD women, oral estrogen replacement, compared with transdermal estrogen, reduces the action of exogenous GH, necessitating a higher GH dose (34), which is also shown in the present study. Presently used low doses of sex steroids seem not to affect lipid levels negatively (35). Previous mortality studies in craniopharyngioma patients have shown about a three- to ninefold increase in cardio- and cerebrovascular mortality (1-3), which seems to be even greater in estrogen-deficient women (3). Sixty-five percent of the craniopharyngioma females had late puberty induction but were then successfully treated with estrogens of 1-2 mg daily without interruption. No significant correlations between age at puberty induction/ menarche in relation to BMI or other CVD indicators were recorded. Whether late puberty induction together with the presently used low estrogen doses may influence cardiovascular risk needs, however, longer follow up in larger cohorts of female patients. Low levels of serum DHEA and testosterone were recorded among the female patients indicating 'androgen deficiency', which is associated with increased CVD risk $(36,37)$. Taken together, late puberty induction and rather low doses of estrogen substitution together with a lack of androgens may have influenced the increased CVD risk seen among the female craniopharyngioma patients in the present study.

GH therapy normalizes $11 \beta$-hydroxysteroid dehydrogenase 1 activity in GHD subjects (38), and only two GHD patients were presently not receiving GH. In addition, most men and women were treated with low doses of replacement hydrocortisone (39), even though some exceptions occurred in five patients with extreme obesity. It has been suggested that the hydrocortisone dose may need to be increased in patients up to the weight of $120 \mathrm{~kg}$ (40). However, importantly, no significant correlation between fat mass and the hydrocortisone dose was shown in the present study, and only a few patients received higher than standard hydrocortisone doses. Equally, while hypothyroidism is a recognized risk factor for CVD (41), the medium serumfree $\mathrm{T}_{4}$ was slightly higher, but in the normal range, and not considered related to the increased cardiovascular risk in the female patients. Overall, hormone replacement is rather unphysiological in these patients and even if selected biochemical parameters may be reassuring they do not guarantee health. The slight over- or under treatment in the present study cannot, however, explain the very high cardiovascular risk recorded among the females or in the TGTV group.

In summary, at a median age of 28 and 20 years after surgery, patients with a CO craniopharyngioma, especially those with TGTV, have persistently increased CVD risk. Conventional hormone replacement, including long-term GH therapy, was insufficient to normalize CVD risk, suggesting an important role for irreversible hypothalamic damage. It is possible that late puberty induction and the lack of androgens might be of importance for the increased CVD risk among the female patients, which needs further investigations.

\section{Declaration of interest}

E-M Erfurth is a member of Eli Lilly and Company Advisory Board. The other authors have nothing to disclose.

\section{Funding}

This work was supported by the Swedish Research Council (grant no. K 2002-72X-14257-01), the Swedish Children's Cancer Foundation, the Medical Faculty, Lund University, Sweden, and the Serbian Ministry of Science (grant no. 145019). A generous grant was provided by Novo Nordisk Scandinavia AB.

\section{References}

1 Bülow B, Attewell R, Hagmar L, Malmstrom P, Nordstrom CH \& Erfurth EM. Postoperative prognosis in craniopharyngioma with respect to cardiovascular mortality, survival, and tumour recurrence. Journal of Clinical Endocrinology and Metabolism 1998 11 3897-3904.

2 Tomlinson JW, Holden N, Hills RK, Wheatley K, Clayton RN, Bates AS, Sheppard MC \& Stewart PM. Association between premature mortality and hypopituitarism. Lancet 2001357 425-431.

3 Pereira AM, Schmid EM, Schutte PJ, Voormolen JH, Biermasz NR, van Thiel SW, Corssmit EP, Smit JW, Roelfsema F \& Romijn JA. High prevalence of long-term cardiovascular, neurological and psychosocial morbidity after treatment for craniopharyngioma. Clinical Endocrinology 200562 197-204.

4 De Vile CJ, Grant DB, Hayward RD \& Stanhope R. Growth and endocrine sequelae of craniopharyngioma. Archives of Disease in Childhood 199675 108-114.

5 Karavitaki N, Cudlip S, Adams CB \& Wass JA. Craniopharyngiomas. Endocrine Reviews 200627 371-397.

6 Müller HL, Emser A, Faldum A, Bruhnken G, Etavard-Gorris N, Gebhardt U, Oeverink R, Kolb R \& Sorensen N. Longitudinal study on growth and body mass index before and after diagnosis of childhood craniopharyngioma. Journal of Clinical Endocrinology and Metabolism 200489 3298-3305.

7 Bray GA, Inoue S \& Nishzawa Y. Hypothalamic obesity. The autonomic hypothesis and the lateral hypothalamus. Diabetologia 198120 366-377. 
8 King BM. The rise, fall and resurrection of the ventromedial hypothalamus in the regulation of feeding behaviour and body weight. Physiology and Behavior 200687 221-244.

9 Lustig RH. Autonomic dysfunction of the beta-cell and the pathogenesis of obesity. Reviews in Endocrine and Metabolic Disorders $2003423-32$.

10 Roth C, Wilken B, Hanefels F, Schröter W \& Leonhardt U. Hyperphagia in children with craniopharyngioma is associated with hyperleptinaemia and a failure in the downregulation of appetite. European Journal of Endocrinology 1998138 89-91.

11 Harz KJ, Müller HL, Waldeck E, Pudel V \& Roth C. Obesity in patients with craniopharyngioma: assessment of food intake and movement counts indicating physical activity. Journal of Clinical Endocrinology and Metabolism 200388 5227-5231.

12 Srinivasan S, Ogle GD, Garnett SP, Briody JN, Lee JW \& Cowell CT. Features of the metabolic syndrome after childhood craniopharyngioma. Journal of Clinical Endocrinology and Metabolism 200489 81-86.

13 Geffner M, Lundberg M, Koltowska-Häggström M, Abs R, Verhelst J, Erfurth EM, Kendall-Taylor P, Price DA, Jonsson P \& Bakker B. Changes in height, weight, and body mass index in children with craniopharyngioma after three years of growth hormone therapy: analysis of KIGS (Pfizer international growth database). Journal of Clinical Endocrinology and Metabolism 200489 5435-5440.

14 Link K, Moëll C, Garwicz S, Cavallin-Ståhl E, Björk J. Thilén U, Ahrén B \& Erfurth EM. Growth hormone deficiency predicts cardiovascular risk in young adults treated for acute lymphoblastic leukaemia in childhood. Journal of Clinical Endocrinology and Metabolism 200489 5005-5012.

15 Janssen I, Heymsfield SB, Baumgartner RN \& Ross R. Estimation of skeletal muscle mass by bioelectrical impedance analysis. Journal of Applied Physiology 200089 465-471.

16 Alberti KG, Zimmet P \& Shaw J. Metabolic syndrome-a new worldwide definition. A Consensus Statement from the International Diabetes Federation. Diabetic Medicine 200623 469-480.

17 de Ferranti SD \& Rifai N. C-reactive protein: a nontraditional serum marker of cardiovascular risk. Cardiovascular Pathology $20071614-21$.

18 Rifai N \& Ridker PM. Population distributions of C-reactive protein in apparently healthy men and women in the United States: implication for clinical interpretation. Clinical Chemistry 200349 666-669.

19 Walldius G \& Jungner I. The apoB/apoA-I ratio: a strong, new risk factor for cardiovascular disease and a target for lipid-lowering therapy - a review of the evidence. Journal of Internal Medicine 2006259 493-519.

20 Wilhelmsen L, Tibblin G, Aurell M, Bjure J, Ekström-Jodal B \& Grimby G. Physical activity, physical fitness and risk of myocardial infarction. Advanced Cardiology 197618 217-230.

21 Tudor-Locke C, Burkett L, Reis JP, Ainsworth BE, Macera CA \& Wilson DK. How many days of pedometer monitoring predict weekly physical activity in adults? Preventive Medicine 200540 293-298.

22 Fernandez-Real JM \& Ricart W. Insulin resistance and chronic cardiovascular inflammatory syndrome. Endocrine Reviews 2003 24 278-301.

23 Bray GA \& Gallagher TF. Manifestations of hypothalamic obesity in man: a comprehensive investigation of eight patients and a review of the literature. Medicine $1975 \mathbf{5 4} 301-330$.

24 Lustig RH. Childhood obesity: behavioural aberration or biochemical drive? Reinterpreting the first law of thermodynamics Nature Clinical Practice. Endocrinology and Metabolism 20062 $447-458$.

25 Müller HL, Handwerker G, Gebhardt U, Faldum A, Emser A, Kolb R \& Sörensen N. Melatonin treatment in obese patients with childhood craniopharyngioma and increased daytime sleepiness. Cancer Causes and Control 200617 583-589.

26 Roth CL, Hunneman DH, Gebhardt U, Stoffel-Wagner B, Reinehr T \& Müller HL. Reduced sympathetic metabolites in urine of obese patients with craniopharyngioma. Pediatric Research 200761 496-501.
27 Shulman GH, Rothman DL, Jue T, Stein P, DeFronzo RA \& Shulman RG. Quantitation of muscle glycogen synthesis in normal subjects and subjects with non-insulin-dependent diabetes by $13 \mathrm{C}$ nuclear magnetic resonance spectroscopy. New England Journal of Medicine 1990322 223-228.

28 Bunin GR, Surawicz TS, Witman PA, Preston-Martin S, Davis F \& Bruner JM. The descriptive epidemiology of craniopharyngioma. Journal of Neurosurgery $1998 \mathbf{8 9} 547-551$.

29 Clayton PE, Cuneo RC, Juul A, Monson JP, Shalet SM \& Tauber M, European Society of Paediatric Endocrinology. Consensus statement on the management of the GH-treated adolescent in the transition to adult care. European Journal of Endocrinology 2005 $152165-170$.

30 Attanasio AF, Shavrikova E, Blum WF, Cromer M, Child CJ, Paskova M, Lebl J, Chipman JJ \& Shalet SM. Hypopituitary Developmental Outcome Study Group. Continued growth hormone $(\mathrm{GH})$ treatment after final height is necessary to complete somatic development in childhood-onset GH-deficient patients. Journal of Clinical Endocrinology and Metabolism $2004 \mathbf{8 9}$ 4857-4862.

31 Johannsson G, Albertsson-Wikland K \& Bengtsson BA. Discontinuation of growth hormone $(\mathrm{GH})$ treatment: metabolic effects in GH-deficient and GH-sufficient adolescent patients compared with control subjects. Swedish Study Group for Growth Hormone Treatment in Children. Journal of Clinical Endocrinology and Metabolism 199984 4516-4524.

32 Colao A, Di Somma C, Salerno M, Spinelli L, Orio F \& Lombardi G. The cardiovascular risk of GH-deficient adolescents. Journal of Clinical Endocrinology and Metabolism 200287 3650-3655.

33 Verhelst J, Kendall-Taylor P, Erfurth EM, Price AD, Geffner M, Koltowska-Häggström M, Jonsson PJ, Wilton P \& Abs R. Baseline characteristics and response to 2 years of growth hormone replacement of hypopituitary patients with growth hormone deficiency due to adult-onset craniopharyngioma in comparison to patients with non-functioning pituitary adenoma: data from KIMS (Pfizer International Metabolic Database). Journal of Clinical Endocrinology and Metabolism 200590 4636-4643.

34 Mah PM, Webster J, Jönsson P, Feldt-Rasmussen U, KoltowskaHäggström M \& Ross RJ. Estrogen replacement in women of fertile years with hypopituitarism. Journal of Clinical Endocrinology and Metabolism $2005905964-5969$.

35 Sherif K. Benefits and risks of oral contraceptives. American Journal of Obstetrics and Gynecology 1999180 343-348.

36 Lasco A, Frisina N, Morabito N, Gaudio A, Morini E, Trifiletti A, Basile G, Nicita-Mauro V \& Cucinotta D. Metabolic effects of dehydroepiandrosterone replacement therapy in postmenopausal women. European Journal of Endocrinology 2001145 457-461.

37 Arlt W. Androgen therapy in women. European Journal of Endocrinology 2006154 1-11.

38 Giavoli C, Libe R, Cobetta S, Ferrante E, Lania A, Arosio M, Spada A \& Beck-Peccoz P. Effect of recombinant human growth hormone $(\mathrm{GH})$ replacement on the hypothalamic-pituitaryadrenal axis in adult GH-deficient patients. Journal of Clinical Endocrinology and Metabolism 200489 5397-5401.

39 Schneider HJ, Aimaretti G, Kreitschmann-Andermahr I, Stalla GK \& Ghigo E. Hypopituitarism. Lancet 2007369 1461-1470.

40 Mah PM, Jenkins RC, Rostami-Hodjegan A, Newell-Price J, Doane A, Ibbotson V, Tucker GT \& Ross RJ. Weight-related dosing, timing and monitoring hydrocortisone replacement therapy in patients with adrenal insufficiency. Clinical Endocrinology 200461 367-375.

41 Cappola AR \& Ladenson PW. Hypothyroidism and atherosclerosis. Journal of Clinical Endocrinology and Metabolism $2003 \mathbf{8 8}$ 2438-2444.

Received 25 July 2009

Accepted 30 July 2009 